\title{
Análise do envolvimento da proteína NS1 de Dengue virus na modulação da atividade transcricional no promotor de IL-6 em células hepáticas humanas
}

Carneiro, A.C.A.; Reis, A.L.A.; Silveira, P.F.; Ribeira, E.M.; Ferreira, C.S.; Silva. B.M*

Instituto de Ciências Exatas e Biológicas, Universidade Federal de Ouro Preto/MG *e-mail:breno@iceb.ufop.br

\section{Resumo}

Os Dengue virus (DENV) possuem um genoma constituído de RNA senso positivo que expressa proteínas estruturais e não estruturais dentre as quais destaca-se a NS1 que desempenha uma atividade na replicação do genoma viral e pode exercer um papel na modulação de vias sinalizadoras celulares. Esta função foi demonstrada por nosso grupo através de em um modelo de células HepG2 expressando NS1 de forma constitutiva em que NS1 altera o perfil de ativação de proteínas da via NF-kB. Contudo, este trabalho tem como objetivo avaliar através de ensaios de atividade de luciferase, o efeito da expressão da proteína NS1 de DENV na liberação de IL6 em células HepG2, uma vez que altos níveis de IL-6 são detectadas no soro de pacientes infectados e que esta citocina pode ser modulada pela via de NF-kB. Os resultados iniciais mostraram que a expressão da NS1 aumenta a atividade transcricional no promotor de IL-6 nas células HepG2. Além disso, uma mutação pontual no sítio de ligação de um fator transcricional denominado AP-1 (heterodimero de cFOS e cJUN) no promotor de IL-6, resulta na diminuição desta atividade. Adicionalmente, foi verificado que células expressando NS1 tanto de forma transiente como constitutiva apresentam também uma maior atividade transcricional de AP-1 ativado pela via JNK das MAP cinases. Tais dados sugerem que esta via pode também ser regulada em função da presença de NS1. Ensaios complementares estão sendo conduzidos para avaliar possíveis alterações na via MEK/ERK das MAP cinases, que também ativam proteínas constituintes de AP1 e elucidar o mecanismo de ação de NS1 na possível manipulação destas vias. Os resultados obtidos por este trabalho poderão ajudar na compreensão dos mecanismos 
utilizados pelos DENV na modulação da expressão de genes celulares e auxiliar a condução de pesquisas com foco no desenvolvimento de estratégias terapêuticas para combate ao vírus.

Palavras-chave: Dengue virus, IL-6, vias de sinalização, atividade transcricional.

Apoio financeiro: CNPq, CAPES, FAPEMIG e UFOP. 